\title{
Diet and acne vulgaris
}

\author{
Dieta a trądzik pospolity
}

\author{
Nina Wyrzykowska ${ }^{1}$, Michał Wyrzykowski ${ }^{1}$, Ryszard Wiesław Żaba ${ }^{1}$, Wojciech Silny ${ }^{1}$, Marian Grzymisławski ${ }^{2}$ \\ 1Department of Dermatology and Mycology, Poznan University of Medical Sciences, Poland \\ 2Department of Internal Medicine, Metabolism and Nutrition, Poznan University of Medical Sciences, Poland
}

Prz Gastroenterol 2013; 8 (2): 93-97

DOI: $10.5114 / p g .2013 .34834$

Key words: acne, diet, aetiology, treatment.

Słowa kluczowe: trądzik pospolity, dieta, etiologia, leczenie.

\begin{abstract}
Address for correspondence: Prof. Ryszard Wiesław Żaba MD, PhD, Department of Dermatology and Mycology, Poznan University of Medical Sciences, 49 Przybyszewskiego St, 60-355 Poznan, Poland, phone: +48 $601741750,+48618691718$, fax: +48 618691285 , e-mail: ryszardzaba@gmail.com
\end{abstract}

\begin{abstract}
Over the last years many studies have been published that investigated whether diet is associated with the course of acne. Older studies, well known by dermatologists, exclude the role of diet in the pathogenesis of acne; however, they are devoid of strong scientific fundamentals. Recent articles are full of evidence confirming the association between food and the development or aggravation of acne. Also they present different theories about possible food mechanisms of action. In response, there are many published articles that describe contrary theories and that deny the importance of previous publications on the basis of methodological errors. The role of dairy products, chocolate, vitamins, low or high glycaemic load in a diet, or a high-fat diet in the course of acne has been investigated more often. The confirmation or negation of many hypotheses related to the dietary influence on acne still requires further investigation.
\end{abstract}

\section{Introduction}

Acne (acne vulgaris) is an androgen-dependent dermatosis with multifactorial aetiology, characterized by the occurrence of seborrhoea and development of skin lesions in the form of comedones, papules and pustules in the areas rich in sebaceous glands. Acne vulgaris, hereinafter called acne, is one of the most common skin diseases, and is diagnosed mostly in patients between 11 and 30 years of age. It is believed that it affects about $80 \%$ of persons in this age group or even, taking into account even its mild forms, $100 \%$ of persons at puberty.

\section{Streszczenie}

W ostatnich latach opublikowano wiele prac mających na celu potwierdzenie bądź negację wpływu stosowanej diety na przebieg trądziku pospolitego. Starsze badania, dobrze znane dermatologom, odrzucały rolę diety $\mathrm{w}$ patogenezie trądziku pospolitego, jednak nie mają one silnych naukowych podstaw. Nowsze artykuły obfitują w dowody na związek niektórych pokarmów z rozwojem lub zaostrzeniem zmian trądzikowych. Przedstawiają również różne teorie na temat możliwych mechanizmów działania poszczególnych pokarmów. W odpowiedzi publikowane są badania, które opisują przeciwstawne teorie i obalają przy tym ważność innych prac, głównie na podstawie popełnianych błędów metodologicznych. Najczęściej badano rolę produktów mlecznych, czekolady, witamin, diety o niskim lub wysokim tadunku glikemicznym, diety z wysoką zawartością tłuszczów w przebiegu trądziku pospolitego. Potwierdzenie lub negacja wielu hipotez związanych z wpływem diety na trądzik wymaga wciąż dalszych badań.

The lesions, which usually occur in the second decade of life, with time become milder and abate at the end of the decade or at the beginning of the third decade. However, sometimes the disease process continues until the $30^{\text {th }}$ or $40^{\text {th }}$ year of age or even for the whole life [1-4]. Generally, the sooner acne appears, the greater is the probability of its severe and long-term course. Women and men are considered to be affected by acne to the same degree equally often; however, more severe forms of acne are observed mainly in men, which is probably associated with the effect of hormones. Acne affects all human races, but it is less prevalent in Asians and Blacks [4, 5]. 
Acne is a disease of the hair follicles and sebaceous glands. Its aetiology includes four main factors: excessive production of sebum, excessive follicular keratinization and impaired corneocyte desquamation, increased skin colonization by Propionibacterium acnes and the stimulating effect of hormones on the sebaceous glands $[4,6,7]$. Also other factors are considered to be significant, such as endocrinological, emotional, genetic and climatic factors, using creams in the form of occlusive dressings, using drugs or the influence of profession [8]. The skin lesions are located mainly on the face and in the upper parts of the body, and sometimes also in other areas. Due to the localization and chronic nature of acne, it often poses a serious psychological problem for a patient [1]

\section{Diet and acne}

In the last century the role of diet in the pathogenesis of acne was surrounded by many controversies. In the 1930s most dermatology textbooks recommended a restrictive diet to patients suffering from the dermatosis on the basis of clinical experiments that suggested that a diet rich in carbohydrates and sweets may cause aggravation of acne. However, despite a general belief about the effectiveness of such practice, there was still too little evidence supporting the role of diet in the control of the course of acne. For this reason, 40 years later the same dietary recommendations were considered unfounded and were removed from the textbooks. At that time a consensus was formed about no influence of diet on the course of acne in most patients, and such a tendency has remained until today in many guidelines on the treatment of acne. Nevertheless, many patients with acne lesions still believe in the role of diet as a factor aggravating acne. The same belief is observed among last-year medical students from Melbourne. They took part in a study that revealed that as many as $41 \%$ of the respondents considered diet to be a factor that aggravates acne [9]. A similar survey was conducted among 166 acne patients in Jordan [10], when the role of various factors, including dietetic factors, potentially aggravating acne, according to patients subjective assessment and beliefs, was examined. Most patients stated that acne was adversely affected by nuts (89.2\% of the patients), chocolate $(89.4 \%)$, cakes and cookies $(57.2 \%)$, high-fat products $(53.0 \%)$, fried dishes (51.8\%) and eggs (42.2\%). However, the patients reported a deteriorated dermatological state on the basis of their own observations after eating butter or margarine $(21.1 \%)$, milk, yoghurt and cheese $(22.9 \%)$, cream (20.5\%) and spices (10.8\%). In addition, $1.8 \%$ of the patients observed aggravation of acne after eating grains and $12.1 \%$ of the patients considered drinking coffee or tea as a factor that deteriorates the skin state. The examined patients believed in the improvement of their dermatological state after eating a diet rich in vegetables and fruit. On the basis of medical history, the scientists established that most acne patients consumed snacks and sweets, including especially chocolate, nuts, olive oil and fried dishes. They also observed that the patients did not eat sufficient amounts of vegetables and fruit: $81 \%$ of the patients confirmed that they usually consumed a low or moderate amount of vegetables and fruit in their diets, and only $19 \%$ of the patients confirmed high vegetable and fruit content in their diets [10]. A similar study was also conducted in Saudi Arabia - it included 700 students of both sexes, living in different regions of Riyadh. The respondents were asked for their opinions on acne. The study demonstrated that as many as $72.1 \%$ of the persons taking part in the study believed in the role of diet in the aetiopathogenesis of acne [11]. The above scientific reports prove that there is still a strong belief in the social consciousness about a significant role of diet in acne treatment. They also suggest a possible influence of dietary habits on the course of acne.

Initial hypotheses concerning the correlation of acne and diet, proposed by scientists, were based on a few observations that suggested that acne may develop in populations that changed their nutritional style to the Western type. The observations were made during the analysis of relationships between migratory movements and the onset of occurrence of acne lesions. Such a situation was observed among Irish women who emigrated from rural areas to New England and in Eskimos [12, 13]. Also observations made in Kenya, Zambia and among Bantu tribes in Southern Africa revealed that the residents significantly less often suffer from acne in comparison to their compatriots who emigrated to the United States [6]. Definitely less frequent incidence of acne in areas not affected by the Western type diet is still observed. A study on such a population of people was also conducted among the inhabitants of Kitava island in New Guinea, cut off from the world, and among Indians from the Ache tribe in Paraguay. The diet of Kitava inhabitants was based mainly on fruit, fish and coconuts, while Paraguay inhabitants ate mainly products of their own farming, maize and rice. The dermatological examination performed in New Guinea found not a single case of acne. The examined group comprised 1,200 persons, including 300 persons aged $15-25$ years. Also no case of acne was found in the Paraguay population that consisted of 115 persons, where follow-up examinations were conducted for over 2 years [13]. On the basis of these epidemiological studies, an assumption was made that the low incidence of acne in these 
regions is related not only to genetic factors but also, and first of all, to environmental factors, in which a diet rich in products with a low glycaemic index seems to be the most important. Such an assumption is not supported by Thiboutot, who warns against relating aggravation of acne mainly to products with a high glycaemic index, resulting in hyperinsulinaemia, which is characteristic of the Western-type diet, because it would suggest that the dermatosis is more prevalent in obese people and diabetics, while such a relationship is not observed. Thus he proposes bearing in mind the still very significant role of genetic factors in the development of acne [12]. Despite this, many scientists speculate that it is actually the Western-type diet that is responsible for the development of acne. This diet is poor in essential unsaturated fatty acids and the ratio between them is disturbed (the ratio of $\omega-6 / \omega-3$ fatty acids in the Western-type diet is about $20: 1$ in comparison to the ratio of $1: 1$ of the traditional diet), is poor in antioxidants and vitamins, and rich in carbohydrates with a high glycaemic index and trans fatty acids [14]. It was suggested that lack of essential unsaturated fatty acids, such as linoleic and linolenic acid, in the diet results in hyperkeratosis in the excretory ducts of the sebaceous glands and increases the transepidermal water loss, which leads to the aggravation of acne [12, 13]. Brazilian researchers decided to examine more thoroughly the influence of essential unsaturated fatty acids on the course of acne. They introduced daily oral supplementation of essential unsaturated fatty acids in acne patients. After 3 months the used supplementation did not result in an improvement of the dermatological state and only a significant reduction in the size of the sebaceous glands was observed in the histopathological examination of a patient's skin specimen $[6,15]$. It seems possible that extension of time of oral supplementation with these fatty acids may lead to distinct clinical improvement of acne lesions, but such a study has not been conducted yet.

In the last few years attention has been attracted to the role of the effect of adverse diet on acne in the Western-type diet, which is related mainly to the influence of increasing glycaemic load. It modulates the risk of acne lesions by changing the concentration of insulin in blood serum and by the activity of insulin-like growth factor-1 (IGF-1), myogen stimulating proliferation of cells of the excretory ducts of the sebaceous glands, IGFbinding protein-3, and by the retinoid signalling pathway $[12,13,16]$. Hyperinsulinaemia, which leads to an increase in IGF-1 and altogether to a decrease in IGF-1binding protein, contributes to keratinocyte hyperproliferation. It was proved that IGF-1 increases the concentration of androgens, and androgens increase the level of IGF-1, which results in a vicious circle and constant stimulation of sebum production [6]. The author of the study also suggests that the very hyperinsulinaemia related to diet also results in an increase in the production of androgens only, which may be the reason for the aggravation of acne [16]. The assessment of correlations between the glycaemic index of consumed products and the incidence of acne was the aim of a study conducted on a male population between 15 and 25 years of age. Each of the 43 examined persons was randomly assigned to a group fed one of two diet types. Each diet was followed for 12 weeks. The diet in group 1 was based on products with a low glycaemic index, and $25 \%$ of the energy came from protein, 30\% from fat, and $45 \%$ from carbohydrates with a low glycaemic index. The second group was the control group with no change of the former nutritional habits, and the menu was based mainly on carbohydrates with a high glycaemic index. After 12 weeks of the diet, a significant reduction in the amount of acne lesions, both inflammatory and noninflammatory, was observed in group 1 in comparison to the control group $[17,18]$. Despite encouraging reports on the influence of a high glycaemic index on the development or aggravation of acne lesions, some scientists tried to invalidate the theory. A study was published that denied the influence of glycaemic index value and insulin concentrations in blood serum on the pathogenesis of acne [19]; however, it met with considerable criticism from the world of science as the only study that was faulted for contradicting common knowledge.

Also milk as a product with many myths of its alleged adverse effect on acne was subjected to some thorough examination. The Harvard School of Public Health searched for a possible mechanism leading to the stimulation of development of acne lesions in the case of daily milk consumption. It was observed that drinking milk and eating products deriving from a pregnant cow every day exposes us to the effect of hormones produced by these pregnant animals - especially placental progesterone and precursors of dihydrotestosterone, such as $5 \alpha$-pregnanedione and $5 \alpha$-androstanedione. These hormones are closely related in the metabolic pathway to dihydrotestosterone, which is commonly considered as an acnegenic factor. It should be mentioned that there are enzymes determining the transformation of the above cow hormones into dihydrotestosterone in the pilosebaceous units. Unfortunately, even obtaining a total block of $5 \alpha$-reductase, the enzyme that conditions the reaction, would not be successful, since the block would turn out to be useless. This results from the fact that testosterone derivatives present in cow milk were already subjected to $5 \alpha$-reduction in the cow mammary glands. $5 \alpha$-pregnanedione and $5 \alpha$-androstane- 
dione reach the pilosebaceous units and make human organisms exposed to the activity of potential agonists, to which we were not evolutionarily adapted by appropriate immunological defence mechanisms. Not only the presence of dihydrotestosterone derivatives in cow milk seems to have an adverse effect on the course of acne. Other compounds include prolactin, somatostatin, growth hormone-releasing factor, luteinizing hormone, thyroid-stimulating hormone, thyrotropin-releasing hormone, numerous steroid hormones, insulin, epidermal growth factor, nerve growth factor, IGF-1 and IGF-2, transforming growth factor, vitamin $\mathrm{D}$, transferrin, lactoferrin, many prostaglandins, including F2 $\alpha$, erythropoietin, bombesin, neurotensin, vasoactive intestinal peptide, various nucleotides, cyclic adenosine monophosphate and guanosine monophosphate, $\beta$-casomorphins, and even relaxin. It is assessed that of all the above-mentioned chemical compounds, IGF-1 and steroid hormones have the greatest influence on the dysfunction of the pilosebaceous units. It is also believed that the consumed milk may stimulate the synthesis of endogenous IGF-1. It is emphasized that all the above relationships between hormones and the pilosebaceous units require further investigation and analyses. The content of so many growth-stimulating hormones in cow milk is surprising, but it should be taken into account that milk is created above all for the stimulation of growth. These are hormones that teenagers and adults are not adapted to consume. Since in both the animal and the human world milk is consumed by offspring only for a definite short period of time, also the usefulness of drinking milk may be considered. Another controversy results from the fact of drinking milk that is from a species other than human, which may be considered as breaking the laws of nature. It is not a secret that every year our knowledge on the role of hormones and biochemical relationships between the activity of the pilosebaceous units and acne has been expanding. The scientists ask themselves a question about the results of the total effect of endogenous hormones and exogenous hormones, i.e. hormones from cow milk, but the answer to this question still has no strong scientific foundation [20].

Consumption of chocolate and its effect on the course of acne for many years has created numerous controversies. Many studies have demonstrated no significant influence of chocolate consumption on acne lesions. On the other hand, some other studies responded with analyses that showed inaccuracies in the former studies and invalidated conclusions made by the former researchers. Such a situation was observed also in the case of a study conducted in 1965 on 65 patients who first for four weeks ate chocolate bars whose ingredi- ents included chocolate liqueur and cocoa butter. Then the chocolate bars were replaced with other bars, this time without chocolate liqueur and cocoa butter, and the test was extended for another 4 weeks. The dermatological examinations that assessed acne eruptions at the particular stages of the study demonstrated that the consumption of large amounts of chocolate does not affect the course of acne or the composition of secreted sebum [6]. The above study met with criticism of its conclusions. The study was faulted for the fact that in the chocolate bars used in the second stage of research, the above-mentioned eliminated cocoa butter and chocolate liqueur were replaced with hardened plant oils and that the content of sucrose was very high in both bar types (53\% in the bars from the first stage of the research and $44.3 \%$ in the bars from the second stage). The high content of sucrose put the patients at risk of hyperglycaemia and hyperinsulinaemia, i.e. factors commonly considered as responsible for the development of acne lesions. Therefore, one should not state that chocolate has no effect on acne when in the research the chocolate is replaced with some other product whose significant role in the aetiopathogenesis of acne cannot be excluded [21].

For many years vitamin A and zinc have been widely recommended by many authors as factors that reduce comedogenesis. The theory was also supported by a scientific study which consisted in the analysis of the concentration of retinol-binding protein in blood (retinol is a product of tissue metabolism of dietary vitamin A) and analysis of the concentration of zinc in blood. The analysis was conducted on 173 acne patients and on the control group. Acne patients had lower levels of both tested substances, while in patients with severe acne the levels were even lower [22]. The results of this study may confirm the significant role of vitamin A and zinc in the aetiopathogenesis of acne.

It turns out that a diet rich in fibre (minimum 30\% content in diet) has a beneficial effect on acne patients. In 1983, fast and considerable improvement was observed after adding $13 \mathrm{~g}$ of fibre to breakfast flakes eaten every day. Many studies have proved that a diet rich in fibre and poor in fats may reduce the concentration of androgens in plasma and urine of adults [23]. However, this theory, similarly as the others, also requires further investigation.

There are many different dietary supplements available on the market that aim at supporting the basic acne treatment. Their composition often includes various herbs, such as Viola tricolor, pansy herb extract, extract of common dandelion root, pollen extract, and also calcium, phosphorus, magnesium, potassium, whey protein, vitamins $P P, B_{6}, B_{1}, B_{2}$, green tea extract, lacto- 
ferrin, the yeast Saccharomyces cerevisiae and others. Despite good tolerance of dietary supplements by patients, there are still few studies on the subject of their safety and effectiveness of use. According to the American guidelines, herbal substances used in the treatment of acne are comparable with hypnosis or the biofeedback method and they are determined as grade B evidence, class II [24].

Despite many reports on the influence of diet on acne, there are also quite sceptical opinions about the subject. Thus the American guidelines indicate that restrictive diets that consist in elimination of specific food products or food groups from the daily diet of an acne patient do not exhibit a beneficial effect in the treatment of this dermatosis. The American scientists claim that former reports and scientific studies on the role of diet in acne are too scarce and thus their conclusions cannot determine standards of conduct in the treatment of acne. They also fault previous studies for not showing relationships between chocolate and sugar consumption and acne in detail. Therefore, they exclude the role of diet in acne and mark diet with grade $B$ evidence, class II [25, 26].

\section{Summary}

The degree of relationships between the Westerntype diet and the incidence of acne still remains controversial. Many recent studies have proved that a diet with low glycaemic load, which imitates the diet in areas without occurrence of acne, significantly reduces the amount of acne eruptions and affects hormonal factors that are important in the development of acne (insulin, androgens, IGF-1). However, many studies are still required for diet to be listed among the guidelines in the whole world as one of the methods of acne treatment. Such studies would have to use the dietary elements that are consumed in areas without the occurrence of acne, such as low-processed products, cereal flakes, dairy products, refined sugar, large amounts of fresh fruit, vegetables, low-fat meat, fish and seafood.

\section{References}

1. Bergler-Czop B. Aetiology of acne vulgaris - review of present literature. Postep Derm Alergol 2010; 27: 467-76.

2. Bergler-Czop B, Brzezińska-Wcisło L. Clinical dissimilarities and acne treatment in the case of adult women - introductory testing. Postep Derm Alergol 2006; 23: 258-62.

3. Bergler-Czop B, Brzezińska-Wcisło L. Methods for treating various forms of acne in the years 1991-2000, Department of Dermatology, Silesian Medical School. Wiad Lek 2005; 58: 156-60.

4. Burgdorf WHC, Plewig G, Wolff HH, Landthaler M (eds.). Braun-Falco Dermatology. Czelej, Lublin 2010; 1019-26.

5. Wolska H, Gliński W, Placek W. Acne vulgaris: pathogenesis and treatment. Consensus of the Polish Dermatological Society. Przegl Dermatol 2007; 24: 171-8.
6. Costa A, Lage D, Abdalla Moises T. Acne and diet: truth or myth? An Bras Dermatol 2010; 85: 346-53.

7. Rokowska-Waluch A, Gąska A, Pawlaczyk M. The course of acne vulgaris in patients' opinion. Postep Derm Alergol 2009; 26: 34-40.

8. Escalante-Jibaja E, Saettone-León A. Acné y dieta. Dermatol Peru 2006; 16: 61-5.

9. Smith R, Mann N. Acne in adolescence: a role for nutrition? Nutrition Dietetics 2007; 64 (Suppl. 4): S147-9.

10. El-Akawi Z, Abdel-Latif Nemr N, Abdul-Razzak K, et al. Factors believed by Jordanian acne patients to affect their acne condition. East Mediterr Health J 2006; 12: 840-6.

11. Al-Hoqail IA. Knowledge, beliefs and perception of youth toward acne vulgaris. Saudi Med J 2003; 24: 765-8.

12. Thiboutot DM, Strauss JS. Diet and acne revisited. Arch Dermatol 2002; 138: 1591-2.

13. Cordain L, Lindeberg S, Hurtado M, et al. Acne vulgaris: a disease of Western civilization. Arch Dermatol 2002; 138: 1584-90.

14. Zouboulis CC, Eady A, Philpott M, et al. What is the pathogenesis of acne? Exp Dermatol 2005; 14: 143-52.

15. Costa A, Alchorne M, Michalany N, et al. Acne vulgar: estudo piloto de avaliacao do uso oral de acidos graxos essenciais por meio de analises clinica, digital e histopatologica. An Bras Dermatol 2007; 82: 129-34

16. Mancini JA. Incidence, prevalence, and pathophysiology of acne. Adv Stud Med 2008; 8: 100-5.

17. Smith R, Mann N, Braue A. A low-glycemic-load diet improves symptoms in acne vulgaris patients: a randomized controlled trial. Am J Clin Nutr 2007; 86: 107-15.

18. Smith RN, Mann NJ, Braue A, et al. The effect of a high-protein, low glicemic-load versus conventional, high glycemic-load diet on biochemical parameters associated with acne vulgaris: a randomized, investigator-masked, controlled trial. J Am Acad Dermatol 2007; 57: 247-56.

19. Kaymak Y, Adisen E, Ilter N, et al. Dietary glycemic index and glucose, insulin, insulin-like growth factor-I, insulin-like growth factor binding protein 3, and leptin levels in patients with acne. J Am Acad Dermatol 2007; 57: 819-23.

20. Danby FW. Acne and milk, the diet myth, and beyond - commentary. J Am Acad Dermatol 2005; 52: 360-2.

21. Cordain L. Implications for the role of diet in acne. Semin Cutan Med Surg 2005; 24: 84-91.

22. Michaelsson G, Juhlin L, Vahlquist A. Effect of oral zinc and vitamin A in acne. Arch Dermatol 1977; 113: 31-6.

23. Poletti Vázquez ED, Muñoz Sandoval MdR. Acné, dieta y debate: un veredicto pendiente. Med Int Mex 2008; 24: 346-52.

24. Strauss JS, DP Krowchuk, Leyden JJ, et al. Guidelines of care for acne vulgaris management. J Am Acad Dermatol 2007; 56: 651-63.

25. Dev Acharya U, Welz K, Rajchel A, et al. The role of benzoyl peroxide in prevention of development of antibiotic-resistant Propionibacterium acnes during combined treatment with erythromycin and tretinoin. Postep Derm Alergol 2009; 26: 134-41.

26. Czarnecka-Operacz M, Jakubowicz O. The role of skin care procedures in acne treatment. Przegl Dermatol 2010; 97: 335-41. 